\title{
The Sound of Maracá and he Silence of History: Toré as religious self-affirmation of the Xukuru-Kariri people in Palmeira dos Índios- Alagoas state, Brazil
}

\author{
Maria Aparecida Oliveira dos Santos \\ Master's Degree student in African Cultures, Diaspora and Indigenous People \\ University of Pernambuco (UPE) \\ Garanhuns, Pernambuco state-Brazil \\ Ricardo Jose Lima Bezerra \\ Permanent Lecturer in the Postgraduate Studies Program in African Cultures, \\ Diaspora and Indigenous People \\ Professor Doctor of the University of Pernambuco (UPE) \\ Professor Doctor Higher Education Council of Garanhuns (AESGA-Garanhuns) \\ Garanhuns, Pernambuco state-Brazil
}

\begin{abstract}
The Toré practice is a cultural identity element of the Xukuru-Kariri people of the Mata da Cafurna in Palmeira dos Índios city, Alagoas-Brazil, a manifestation of the religiosity of an indigenous ethnic group that has been territorialized in this region. However, the Toré experience, just as the natives themselves, suffered and suffers, along the past and the present, resistance and invisibilization, proper to the process of ethnic coloniality suffered by the Xukuru-Kariri in the region by the non-indigenous surrounding society. In this way, the purpose of this text is to characterize and understand the Toré between Xukuru-Kariri this place and the role of this identity and religious manifestation of this ethnic group.We seek, therefore, to understand, through the religious self-assertion that the Tore represents for this ethnic group, ways to overcome discriminatory and deleterious practices typical of the colonialist internal strategies of domination, oppression and conservation.
\end{abstract}

Keywords: Ethnic identity; Toré, Indigenous in Alagoas State-Brazil; Invisibility.

\section{Introduction}

The village Mata da Cafurna of the Xukuru-Kariri people is located in the Municipality of Palmeira dos Índios, Alagoas state, Brazil, located in the mesoregion of Agreste, possessing a privileged geographic location because it is border between the states of Alagoas and Pernambuco and transition zone between the humid region and thenortheastern semiarid backwoods; the territory is marked by several sources of potable water, temporary rivers, water dams, which makes it the so-called "brejo de altitude", high swamp. The city is a mountain range where small farmers live and eight indigenous communities of the Xukuru-Kariri people, among them the Mata da Cafurna, the object of this study.

The name of the Municipality was given in reference to the first inhabitants and the abundance of palm trees in their fields. The Indians settled between the swamp called Cafurna and the Serra da Boa Vista, areas of difficult access, strategies to protect themselves from the action of colonizers in the interior of the Northeast, where they developed their cultural and religious practices, facing a space favorable to growth population and ethnic empowerment.

Studying the history of the Xukuru-Kariri people is a challenge because to demystify existing prejudices and stereotypes about indigenous identities is to perceive the contribution of these people to the territorial and historical formation of the municipality, showing their protagonism in the relations of domination that culminated in moments of conflict, denial and subsequent ethnic emergence.

During the settlement period in the 18th century in Alagoas, non-Indians usurped indigenous lands by killing animals, destroying forests, rivers and part of their living space, erecting fences, setting boundaries and creating tools of social control. Because of this, most of the spaces considered sacred were desecrated and privatized in the desire to build the city. Since then, there have been suffering and persecutions that have been minimized over time by indigenous peoples, thanks to their persistence in claiming their rights to legislation that ensures the practice of a specific and differentiated culture, under the terms of the Brazilian Federal Constitution 1988, in articles 215and 231*. 
From this vision emerged the need to study the Xukuru-Kariri people and give visibility to the resistances they carried out, focusing on the strength, faith and courage undertaken in the movements of resistance to the invaders. In this role, the Tore is configured as the practice that gives unity, models the identity and erects the necessary borders to its existence.

Although the Toré is an important diacritical for the Indians of the Northeast, there has been little academic production in this area, due to the silence of the Indian on matters involving his sacred.Little information is associated with public presentations in the villages or in the external festivities, where it performs performatically without religious character, more representative. In the village, the Toré, as a religious ritual, is maintained as a cultural and frontier secret for the need to strengthen the group and avoid losing the only element defined by the State as an ethnic identifier.

\section{From Silencing to Protagonism}

In the sixteenth century contact with the European and Catholic missions culminated in the extinction of several indigenous peoples, caused by numerous events, that is, they were expelled from their natural habitat, persecuted, forced to make migrations and some fled to places they considered safe. This contact with the European and with the church brought the invisibility of several peoples, according to Moreau:

They are people who have no knowledge of God, nor do idols do what they are told. I have worked to take from your tongue the prayers and practices of our Lord, and I can not even find a language that I know how to say, because they are so gross that they have no vocabulary. (MOREAU, 2003, p.113).

According to this description, the image that the European constructs of the native as an individual without faith and without religion appears, which justified the missions' intention to save these people and, through religious teachings, to have them incorporate Christianity and, consequently they would be saved. This was the background to justify the creation of the Missions, reductions and domination.

It is worth emphasizing that the Indians adopted passivity as a form of silencing, enjoyed much of the European culture, but using disguises as the invisibility of their practices and the passivity of some actions as a strategy to maintain their culture. Therefore, many fled and crossed the hinterlands in search of refuges, settled in high places to escape the strong threat of the colonizer and preserve their cultural traits. An example is the Tore ritual and the Ouricuri that has been kept is practiced to this day. In this perspective, mainly in the Brazilian Northeast, they elaborated various forms of political, economic and cultural survival, among which silence and invisibility, as according to Silva Junior.

The perspective of invisibility corresponded to not showing evidence of belonging to an ethnic group, not to suffer, or to minimize, persecutions at the local level. It was an apparent retraction of the Indians, that is, a strategic retreat to the open confrontation with the surrounding society. This invisibility can be interpreted as being apparent, circumstantial and momentary, since the elaboration and utilization of this strategy considered, besides the different forms of relationship of the Indians with the surrounding society, the different moments of this relation. (SILVA JUNIOR 2007 p.19).

In this context, the idea of invisibility was considered as a strategy to stay and survive in their places of origin, living and outlining a superficial relationship with the society of their surroundings, so that this invisibility assured them the necessary conditions to wait for the moment of resurgence and be able to reaffirm their identity.

In the Brazilian Northeast, this situation is very visible, because the indigenous communities of this region suffered, with the extinction of their villages and with the imposition of European culture, more than other peoples of any other region. This landmark is more visible in the municipality of Palmeira dos Indios-AL, which houses the XukuruKariri people - Mata da Cafurna is a living example of the use of silencing, since these people, even repressed and silenced by the so-called 'white man', continued, even if in secret, practicing its rituals and transmitting it to the new generations, so that such practice would not be forgotten. According to Silva Junior.

High morning. The Toré, a rhythm marked in half-light matches in the back of a house on the outskirts of the town of Palmeira dos Indios, in the alagoan countryside, lashed the night, unnoticed by the society of Palmeiras. The neighborhood was not suspicious, but it was being written here in the history of the Xucuru-Kariri. (SILVA JUNIOR, 2007, p.32).

The Toré came to be practiced in silence, using precariously some instruments and using other tools and methods in order to protect their knowledge to pass them on to future generations, or sought to perform their rituals without making noise, the half light, in the backyards of the houses. In this way, the strategy was as important as faith to ensure the existence of an ethnic group and to preserve manners. In this perspective in 1910 with the advent of the Republic was created the Service of Protection to the Indigenous (SPI), this existence it would guarantee rights and more visibility for their villages; with this, the groups began to take a more incisive and active attitude towards their needs and aspirations. 
Over time, the Xukuru-Kariri began to express aspects of their culture as a way for society to realize thatthese people have an identity that characterizes it; for this, some villages began to perform presentations of the Toré dance, to the non-Indians, as an identity symbol of their ethnic groups. Another benefit is the Brazilian Federal Constitution of 1988, it is considered a historical landmark in the fight for the rights of indigenous peoples. "From the Magna Carta, built from the perspective of the Democratic State of law, the principles of citizenship and human dignity were guaranteed beyond sovereignty and political pluralism" (MIRANDA, p.42, 2017). In this perspective we analyze a look at these groups placing them as protagonists of their history and with this we understand under the terms of the Brazilian Federal Constitution of 1988, articles 215, 231.

\section{TORÉ: silence to strengthen}

The indigenous peoples of the Brazilian Northeast are known to practice a type of ritual known as Toré, strong bond of union of the group, has become a symbol of identity, religion, culture and claim. It is a ritualistic, circular dance marked by strong footsteps with the right foot, accompanied by the sound of maracás. It is listed as an identity mark of the indigenous peoples of the Brazilian Northeast, which is why its essence is not presented to non-indigenous people. This interdiction is salutary in order not to vulgarise or to lose the essence of this cultural element that characterizes and strengthens the indigenous society, so silenced for years, but which reconfigures itself to be strengthened every day.

From this point of view, we analyze that the most important cultural element for these groups is the Toré practice, an act that is both political, religious and aesthetic and that is within the field of ethnology of indigenous peoples. It is a ritualistic dance performed to thank for some grace achieved. It can be performed publicly, receiving a more performative, popular and festive connotation; or it may be limited to the sacred space of the Ouricuri, where there is interdiction to non-Indians. About the choreography, Peixoto emphasizes that

During the choreography, the circle always turns to the right side to evoke the positive forces on its participants. Women and children dance out of the main circle composed of men, in some torés, there may be formation of couples who develop a different ballet of group dance. At that moment, the couples rotate backwards, but never to the left. (PEIXOTO 2013, p.04).

In this description, it is observed how the Tore dance is configured in the indigenous communities; is a choreography that must contain the right steps, in the determined sense, in order not to attract negative forces and, in the whole, each individual has its role in the performance, having specific and well defined moments and places for women, men and couples.

It is very significant for the indigenous groups, because it is a ritual that was left by the ancestors, who despite having suffered with the process of colonization managed to maintain, re-signify and transmit elements of these practices that are configured as an identity element, as tradition religious or as folguedo performed in times of joy to thank a gift received or even in moments of sadness when it assumes the role of source of energy, strength and unity. Through Toré, many indigenous groups contemplate their own existence, a situation that Clarice Mota is emphatic in stating that:

[...] I think of toré as a group invention, as a way for these societies to contemplate their existence by faith, not necessarily religious, but faith in the group as an ethnic community from the pre-colonization tribes. I perceive the tore by interpreting the native texts about it and its performances as an awareness of the group as something separate, immutable and indestructible, which is legitimized by such performances that they believe to have been an ancestral heritage. (MOTA, 2005, 174).

In this scenario, the Toré is a religious practice, where each individual adopts it with the conscience of not letting this cultural element finish. As a ritual, it has the power to give unity to the group, generating a climate of harmony; it contributes, still to build bonds of friendship and the feeling of ethnic belonging, fundamental elements for the life in group.

The Toré was considered wrong, sinful, polytheistic, satanic even an instrument of rebellion by Europeans. Therefore, the colonized, persecuted by the Jesuits and missionaries, getting to have its practice prohibited and its practitioners persecuted, fought against him. The European Christian perspective placed the Toré as a shield that made it difficult for the church to enter and the conversion of the Indians to Catholicism. However, with the prohibition of practicing their rituals, many indigenous peoples preferred to remain invisible and silent, as a means of strengthening and keeping their culture alive, avoiding conflicts, persecutions, arrests and deaths. In this way, preserving the elements that from that time on it differs from the colonizer and, since the Federal Constitution of 1988, were used to ensure their escape from hiding and ensure ethnic and identity recognition. 


\section{TORÉ: performance and folgosity of a people}

The Toré is a symbolic ritual that serves to express the identity of the individual in the group. Because it is the link with the supernatural, with the sacred, with healing; through him they meet to thank their loved ones for the moment, for the joy and it is in him that they find the courage to overcome the world outside the village, because the indigenous people still live at the mercy of the prejudice that so much harms their lives.

The Toré as "cultural performance" of indigenous peoples is of great importance for the group since they place all their faith in the sacred and during the celebrations or rituals at the time of the rite, have unconscious characteristics going to have different performances and this (NEVES, 2005p.130-131) "performance is an interdisciplinary concept that serves not only for the study of so-called complex societies but also for traditional calls".

In this context, the Toré presents several social, cultural changes and characteristics that call them as an ethnic society, taking lessons that were left by their ancestors to perpetuate to future generations, where through it the individual begins to reflect on his history and the world as cited Tuner, 1987 apud Neves (2005):

The ritual is an important moment of reflexivity of the group, because during the performance act the subject is able to reflect on himself and the world. Therefore, ritual is a transforming performance in which important classifications, categories and contradictions of the cultural process are revealed. (NEVES, 2005, p.130)

According to Neves (2005), it is perceived that through the performance act, the individual encounters his ancestors and is closer to reflect on his group and his identity and this classification is of utmost importance for the cultural category of the indigenous peoples.

At the moment of the Toré dance performances are perceived as intensified behavior, which contains ritualistic aspects, repetitions of rhythms and through these movements seek to understand gestures, speech and even smell, as emphasized by Neves.

The rite, when viewed through performance, acquires an affective aspect and therefore it is necessary to look for in it all the senses present: the sounds, the speech, the smell, etc. that is, the ritual ceases to be just cognition, in which the message is emphasized, to become a multidimental and multivocal experience. (NEVES, 2005, p.131).

Among the Xukuru-Kariri, Toré is practiced by people of all age groups, from children dancing in their parentes lap to older adults; for them, to sing and dance this rhythm is to keep alive the flame of culture, to celebrate historical events, it is a time of healing and liberation. Their songs speak of pain, joy, birds, trees, enchanted, among other subjects. Many times, this musical art happens in the few words that they know of the native indigenous language, as a way of trying to keep alive this characteristic of the native culture.

The Toré is a ritualistic dance that happens in three moments; is enveloping through its cadenced ballet to the sound of maracás and marked by the beat of the foot on the ground, by the symbological performance performed in a circular way, in pairs, groups or individually. In the first moment, the ritual takes place in Ouricuri, sacred space reserved only for the indigenous peoples, moment of healing and liberation where the non-Indian cannot enter and not know what happens. In the second moment, it happens in the village, in the form of a presentation where the non-Indian can enter the dance, after the invitation of the dancers. In the third moment, it is a joke in the form of a joke that happens outside the villages in public feasts when they present themselves to non-indigenous.

The following images highlight the execution of the Toré dance in the village of Mata da Cafurna in Palmeira dos Índios City, Alagoas State, Brazil.

\section{Photo 1 depicts non-Indian participation in dance.}

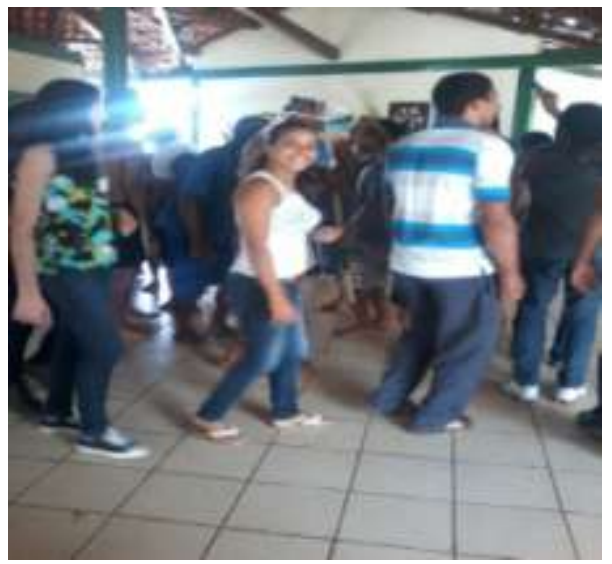


At this moment we are invited to participate in the ballet, where our sim is fundamental for our field research. And it was from this direct contact with the Toré that I decided to research this religious manifestation and give more visibility to these peoples.

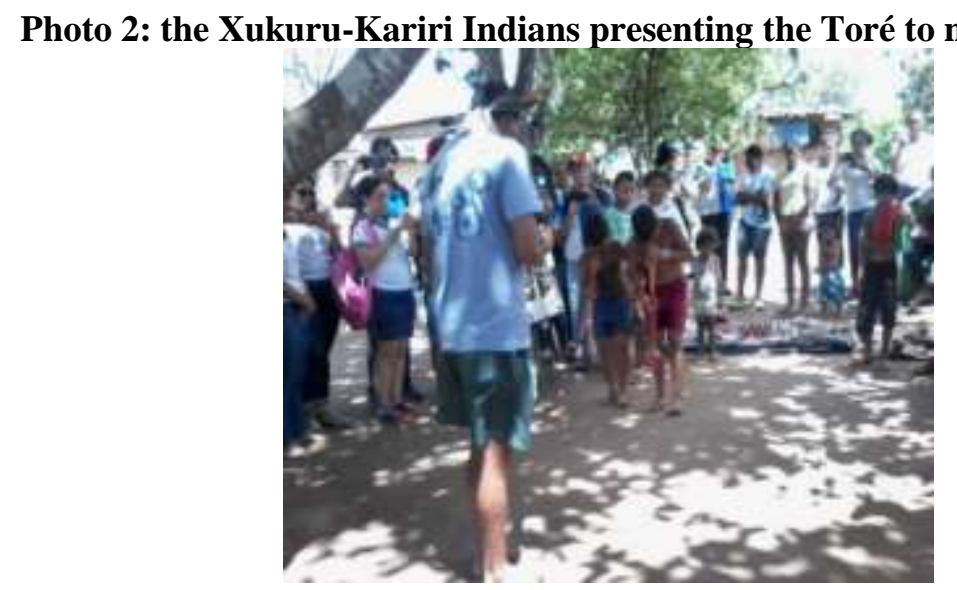

Source: Personal collection, 2017.

When they present themselves to non-Indians, they begin to divulge their identity brand that is currently exposed in society; is, for many, one of the elements that folklore is part of Brazilian culture, and to present themselves outside the village, do not run the risk of losing their identity, for as highlights (MOTA, 2005, p.180) "The Tore of play is one that can present the outside world to tourists and foreigners, because it does not imply loss of their right to a tribal secret. "

The following image was produced in public presentation and represents one of those moments in which the culture is presented without jeopardizing the ritualistic meaning, but with the purpose of generating approximation with the audience that watches the performance.

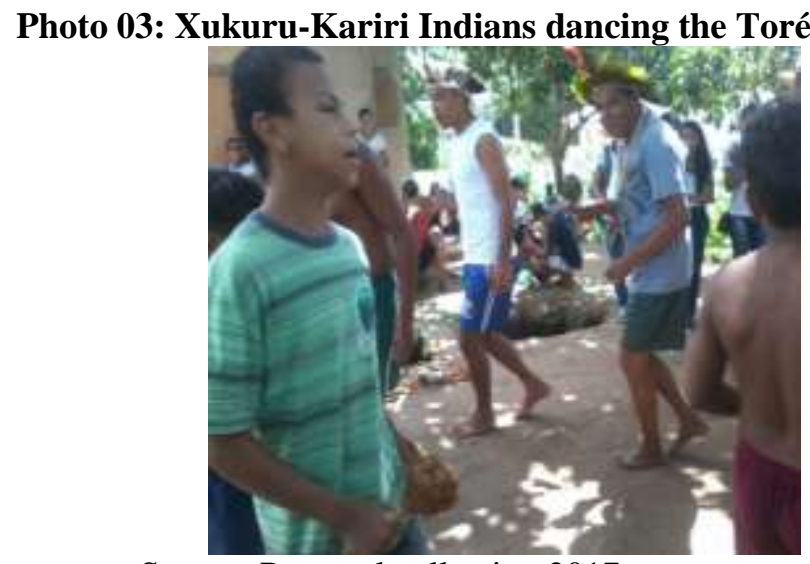

Source: Personal collection 2017

The variations in the types or modalities of the Toré, with or without typical clothing of the Indian, have no relation with greater or less importance, because as a ritual, what matters for indigenous peoples and especially for the XuKurukariri is to dance and sing in faith and devotion and always keep alive its originality.

The indigenous community of Alagoas currently has its villages open for visits and interviews, many of the community members go to the city and relate to other types of people, but they do not go beyond what is allowed by the leaders. When interviewing one of the community leaders, asking why the natives decided to take the Toré to the city. He replied that today they leave the village to the city to introduce themselves to the non-Indians as a way of affirming themselves as indigenous peoples and also the people observing that it has an identity that must be maintained among the indigenous groups. It is emphasized that this contact does not imply in breaking the secret of the group.

\section{The Toré as cultural self-affirmation of the Xukuru-Kariri people.}

Toré enters the history of Xukuru-Kariri people as indispensable for the recognition of their ethnicity, as very important diacritical identity in demarcation of their lands and the maintenance of a cultural autonomy to affirm themselves as Indigenous. In this context, the Toré gains a symbology for the strengthening of an identity. "I am an brazilian indigenous because I have my secret ritual and I also have Toré "(CUNHA, 2008, p. 28). 
For the Xukuru-Kariri people, Toré means TO-sound, RÉ-scream, and this tradition characterizes an essential condition of the identity of the peoples originating in Brazil. The history of the visibility of the Xukuru-Kariri is intimately linked to Lenoir Tibiriçá, a former pajé from the Kariri-Xocó village of Porto Real do Colégio, who, when marrying a Xukuru-Kariri, joined the group, time inserted elements of the Toré of its people of origin, resignifying the local practices and strengthening the notion of sacred inside and outside the village. With this, Toré became the main identity brand, gaining respect and a prominent place in the public appearances of the indigenous group of Palmeira dos Índios, Alagoas, but, as it took on this role in identity, it became a frontier in its sacred terreiro, in the denominated ritual of Ouricuri.

Among the Xukuru-Kariri, Toré is practiced by people of all age groups, from children dancing in their parents' lap to older adults; for them, to sing and dance this rhythm is to keep alive the flame of culture, to celebrate historical events, it is a time of healing and liberation. Their songs speak of pain, joy, birds, trees, enchanted, among other subjects. Many times, this musical art happens in the few words that they know of the native indigenous language, as a way of trying to keep alive this characteristic of the native culture. It is defined as something very particular, reserved and special, as seen in the concept given by Lenoir Tibiriçá 2017: "The Toré it is a song, a dance where we can show the white, for us to say that we have a song, we are Indians ".

The musicality of the Toré among the Xukuru-Kariri is a transmission of knowledge and vibration to thank Tupã (the main divinity of this population) for the graces obtained, it is a way of communicating with the other members of the group, since their rites have several meanings and interpretations and the lyrics of the songs reveal a lot of mystery, as Tania Xukuru-Kariri points out:

For us, Toré is one of the main forms of communication of indigenous peoples, both with God-Nature and with humanity. The singing is the main revealing public manifestation of our identity. Singing is our way of saying "we're here". We survive and nothing will keep us silent! Every corner we become stronger to continue singing our cultures and seeking our rights to live with dignity. We resist and now nothing will stop us from living for many more millennia, happy and peaceful! (Tania Xukuru-Kariri, apud Gerlic, 2012, p.19).

In the speech of the indigenous, we perceive that the group places in the corner of the Tore to their hopes of strengthening and to see this manifestation as the main form of communication and claim of their rights and ethnic recognition in the surrounding society. The contact with the music and the mysteries and incantations that it endures strengthens them to survive and not silence before the non-indigenous society that marginalizes, invisibilizes, silences and withdraws rights and threatens its continuity.

The Toré encompasses the Xukuru-Kariri in different situations and religious festivities such as those taking place in December with the celebration of the birth of Christ, during the holy week period with the celebration of death and resurrection, in the activities commemorating identity in April Indigenous, June with the June festivities. In any of these festivities there is room for a bonfire and a wheel's toré, usually with the participation of non-Indian guests. Outside of these periods the festivals are internal only for the Xukuru-Kariri and Indians of other invited ethnicities.

\section{Types of Toré practiced by the Xukuru-Kariri}

The Toré receives specific designations according to the intended function. It happens in a circular, rotating way, with the steps marked to the sound of the maracás, the rhythm is usually defined by the song and ends with euphoric shouts where the participants express immense happiness. While choreography, it is an engaging ballet; while religion and language, is very significant for the Xucuru- Kariri, receives various denominations, according to the sense given to it: wheel, crossed, spear, divers, chains, bird and rain types as emphasized Moreira, Peixoto and Silva.

Wheel's Toré which means union of the group among themselves and with others. In this tore , the Indians demonstrate that independent of the situation be of lasting of joy, they are united and firm in their ideals.

Toré crossed represents love in all its senses. For the non-Indian community, it is seen as a sort of ritual that precedes the practice of sex.

Buzo's Toré means war and runs on conflicting moments as a way to seek help from the gods to achieve success in battle. Toré of the diver is a very introspective moment of the group, because it means a moment of deep contact with their spiritual entities.

Chain's Toré symbolizes the alliances signed with all those who value and respect the indigenous culture...

Bird's Toré is one of the highest values of the human being, freedom. Rain's Toré means God's greatness, its power to create and sustain life, to renew the landscape and to renew the spirit of the human being. (MOREIRA, PEIXOTO, SILVA, 2011, p.52-53). 
According to this classification, we realize that the Xucuru- Kariri participate in at least seven types of Tore and are of great relevance both to the village and to the spiritual life of the Indians, since religion defines them as an indigenous nation and is a way of contemplating their essence through faith and the certainty of always keeping the culture alive for future generations.

As seen in photos 04, 05, 06, 07 and 08, we can observe the Xukuru-Kariri Indians in a public manifestation of Toré in the village Mata da Cafurna; performing some types of Torés present in the community, are dressed in traditional robes, cocas, maracás (type rattle), divers and face paintings. Around, people watch the dance and contemplate the indigenous culture being passed between the generations, because the Indians that in this photo appear, are not simply participants, they are the concretization of the knowledge of the ancients that will be a breath of culture guiding the way of 'being Indian 'for future generations.

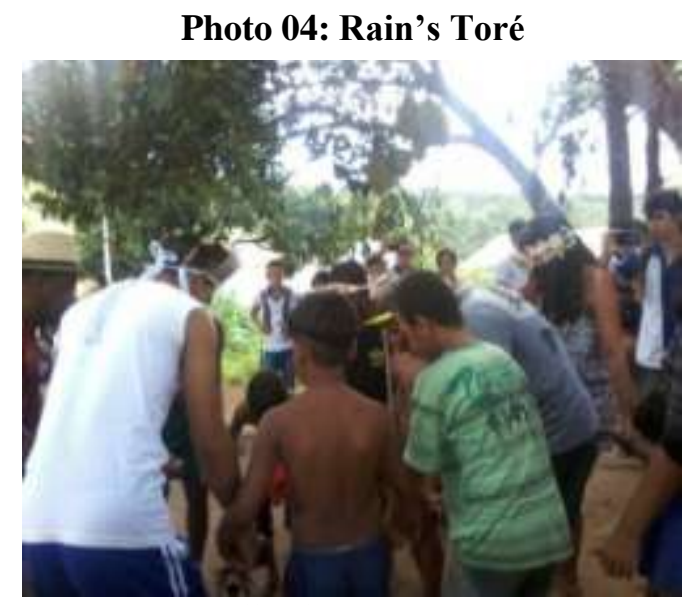

Source: Personal collection, 2016

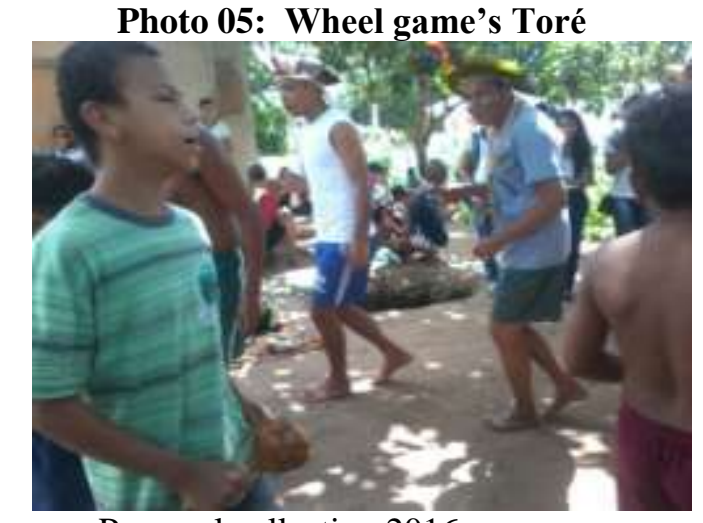

Source: Personal collection 2016

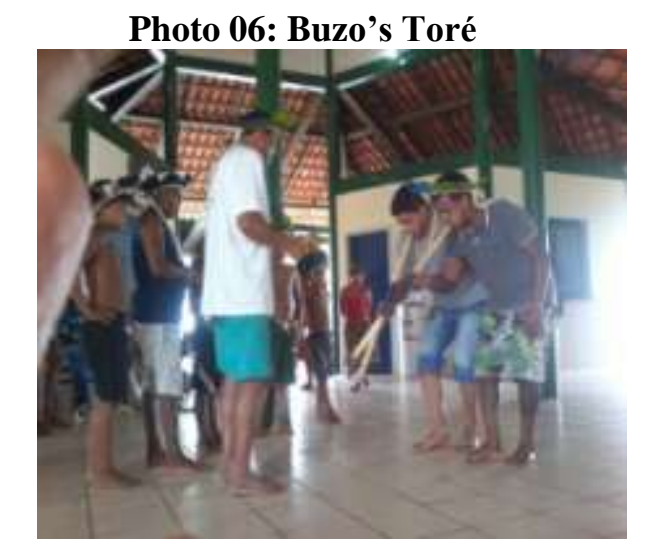

Source: Personal collection 2016 


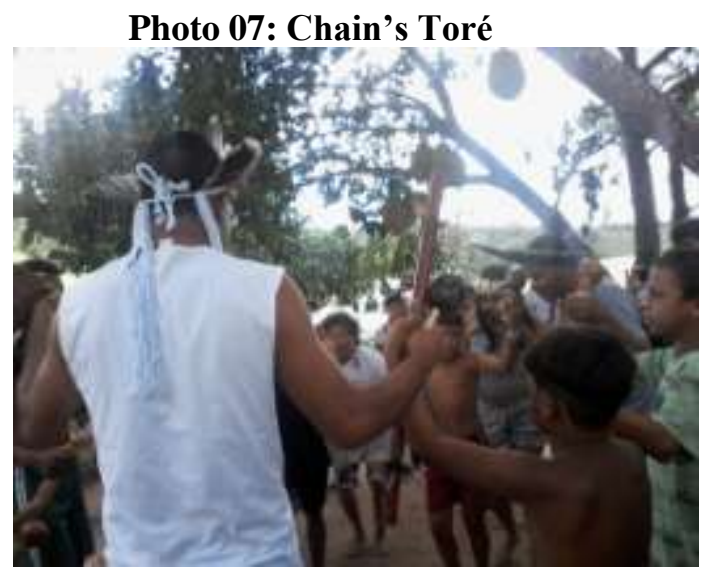

Source: Personal collection 2016

Photo 08: Little Bird's Toré

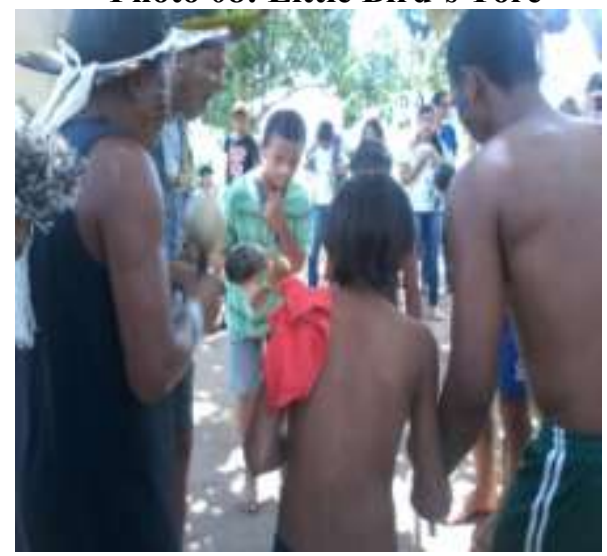

Source: Personal collection 2016

The photographs above characterize their customs a cry of freedom and evidence that even today, after a long process of catechization and doctrinal work engendered by religious missions, some cultural elements remained as diacritics, highlighting the group before the surrounding society.

\section{Final considerations}

In the light of the above, we observed that for years the indigenous peoples lived on massacres and irreparable losses that caused in many villages the loss of their rituals and their mother tongue, being forced to follow a culture different from their own. In this context, we realize that faced with this suffering many groups remained in passivity as a form of silencing, as means to protect their cultures.That is why the Xukuru-Kariri people remained intact their cultures and today are active agents of their own history. In this way, Toré has an emblematic meaning of the ethnicity, culture and religiosity of indigenous peoples, characterized by songs, ritualistic dances, drinking drinks like the jurema that provides access to the spiritual world, where each characteristic has its omnipotent value. In addition, we analyze the Toré in various types of indigenous communities, each with its type of ritualized Toré, that is, each ethnic group has its type of Toré and pass this experience to the other groups in the village.

However, this ritual universe allows a relationship with the surrounding population, that is, the Indians, from there the future generations feel proud of being an Indian, realize its countless value that has in society, that is, the whole of society has the free will to live and to be happy, depending on the ethnicity or religion that it carries out.

Through the Toré we can see that belief at every moment is renewed through some elements such as: request, grace achieved, payment of promise and by this constant contact with the supernatural world. The Torah ritual represents these relationships, it is in this ritualistic universe that the individual feels closer to their religious entities. Considering the above, we observe a high degree of sociocultural responsibility of the social scientist to the study of indigenous causes, where the reseacher in his field research should take direct contact with his research object as a way to help these communities to re-raise their rights and to affirm themselves as indigenous peoples and to realize the importance of their culture for the history of Brazil. This social scientist's contact must be active with his or her research object. 
Therefore, this research aims to contribute to the new indigenous historiography, standing out from the traditional view, dismantling the stereotyped view about these peoples, and contributing to greater visibility in the surrounding nonindigenous society. It shows its power in claiming their rights and constantly seeking their space in society.

*Art. 215. The Brazilian State shall garantee to all the full exercise of cultural rights and access to the sources of national culture, and shall support and encourage the promotion and dissemination of cultural expressions. (Constitutional Amendment no. 48/2005). In Art. 231. Indigenous peoples are recognized for their social organization, customs, languages, beliefs and traditions, and the original rights to the lands they traditionally occupy, and it is for the Union to demarcate, protect and enforce all their property.

\section{References}

Bhabha, H. K. (2014) O Local da Cultura. 2 ed. Belo Horizonte: EDUFMG.

Caminha, P. V. de (2007) Carta a el Rei D. Manuel sobre o achamento do Brasil. São Paulo: Martin Claret.

Gerlic, S. (2011) Índios na visão dos Índios: Somos Patrimônio. Salvador: Thydêwá.

Grunewald, R. de A. (2005) Toré: Regime Encantado do índio do nordeste. Recife: Massangana.

Herbetta, A. F. (2011)Peles Braiadas: Modos de ser kalankó. Doutorado em Ciências Sociais (Antropologia). São Paulo.

Moreira, A. C. de L.; Peixoto, J. A. L.; Silva, T. B. da (2010) Mata da Cafurna: ouvir memória, contar história: tradição e cultura do povo Xucuru-Cariri. Maceió: Edições Catavento.

Mendonça, J. M. de (2000) Os movimentos da imagem da etnografia a reflexão antropológico: experimentos a partir do acervo fotográfico do professor roberto cardoso de oliveira. Campinas: educamp.

Mota, C. N. da (2005) Performance e Significações do Toré: o caso dos Xocó e Kariri-Xocó In: Grunewald, R. de A. (org) Toré: Regime Encantado do Índio do Nordeste. Recife: Massangana.

Neves, R. de C. M. (2005) Identidade, Rito e Performance no Toré Xucuru. In: Grunewald, R. de A. (org) Toré: Regime Encantado do Índio do Nordeste. Recife: Massangana.

Oliveira, J. P. D. Freire, C. A. Da R. (2006) A Presença Índígena na Formação do Brasil. Brasília: Ministério da Educação, Secretaria de Educação Continuada, Alfabetização e Diversidade; Rio de Janeiro: Laced/Museu Nacional.

Silva, C. B. M. Da (2004) Índios do nordeste: temas e problemas. In: Almeida, L. S. (org.) Vai-te para onde não canta galo, nem boi urra... Diagnóstico, tratamento e cura entre os Kariri-Xocó. Maceió: Edufal.

Silva, A. B. Da (2013) Rituais Jiripankó: um olhar sobre o sagrado dos índios do sertão de alagoas. Arapiraca-AL: Monografia (Licenciatura em História Universidade Estadual de Alagoas)

Silva Junior, A. B. Da (2007) Aldeando sentidos: os Xukuru-Kariri e o Serviço de Proteção aos Índios no agreste alagoano. Salvador. 